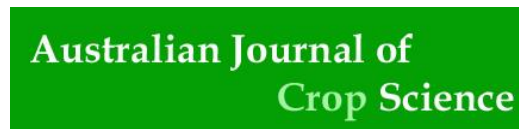

AJCS 11(09): 1216-1220 (2017)

\title{
Agro-industrial quality of plant cane, first and second ratoon in sugarcane varieties
}

\author{
Vinicius Santos Gomes da Silva ${ }^{1}$, Mauro Wagner de Oliveira ${ }^{2}$, Abraão Cícero da Silva ${ }^{1}$, Aleksandro \\ Ferreira da Silva ${ }^{1}$, Elaine Rocha Galvão ${ }^{3}$, Mayame de Brito Santana ${ }^{1}$
}

\author{
${ }^{1}$ Department of Agronomy, University Federal Rural of Pernambuco, UFRPE, Brazil \\ ${ }^{2}$ Department of Agronomy, University Federal of Alagoas - UFAL, Brazil \\ ${ }^{3}$ Department of Agronomy, University of Bahia State, UNEB, Brazil
}

\section{*Corresponding author: abraaocicero@yahoo.com}

\begin{abstract}
The variables related to the agro-industrial quality in sugarcane considered as main tools are being used by producers to choose the varieties to be planted. In general, cultivars that present a better industrial yield for the manufacture of sugar and alcohol have great importance promoting crop sustainability. In this research, the objective was to evaluate the industrial quality of four sugarcane varieties during plant-cane, first and second ratoon crops. The experimental design was a randomized block, with four treatments and five replications. The varieties studied were RB867515, RB92579, SP813250 and VAT90212. In first and second ratoon cycles, the industrial quality of the four varieties was evaluated by determining the fiber content, apparent sucrose (Pol), purity, soluble solids (Brix) and total recoverable sugars (TRS). The results showed that varieties RB867515, RB92579, SP813250 and VAT90212 were similar for agro-industrial quality. In first ratoon crop, only fiber was same between varieties. The RB867515 evidenced larger soluble solids and recoverable sugars. In second ratoon crop, the RB92579 evidenced larger apparent sucrose (Pol) and soluble solids (Brix) and total recoverable sugars (TRS).
\end{abstract}

Keywords: apparent sucrose; fiber; purity; soluble solids; Saccharum spp.; total recoverable sugars. Abbreviations: Brix_soluble solids; Pol_apparent sucrose; TRS_total recoverable sugars.

\section{Introduction}

Sugarcane (Saccharum spp.) is mainly used in the production of sugar and alcohol, as well as for human and animal feeding (Oliveira et al., 2015). It has a large socioeconomic and environmental importance for Brazil, which is currently the world's largest producer. The Brazilian cultivated area covers around 9.0 million hectares, with average yield of $72 \mathrm{t}$ ha $^{-1}$ (Conab, 2016).

The Brazilian sucrose industry is one of the most technical in the world. These advances are the result of research and technologies developed in the country over years. There has been great development in knowledge of plant nutrition, cultivation practices and production management (Oliveira et al., 2014; Simões et al., 2015; Rhein et al., 2016). The researches for high productivity and cost reduction are pursued using several strategies including adoption of varieties that present a better agricultural and industrial yield (Mohammed et al., 2016). Sugarcane improvement programs have made new varieties available with high productive potential. In Brazilian northeast some of these new varieties are RB92579, RB967515, SP813250 and VAT 90212 (Silva et al., 2017a).

Climate factors, especially rainfall volume and distribution, have a great influence on nutrient availability, crop growth rate, nutritional efficiency, yield and sugar quality. For this reason long term evaluation is suggested for productive potential of sugarcane and industrial quality, aiming to contemplate both climatic variations and those resulting from the aging of the crop for at least one year (Silva et al., 2017a;
Silva et al., 2017b).

The current sugarcane payment system adopted by most sugarcane industries in Brazil is based on the total recoverable sugars known as TRS. In this system, the quality of the sugarcane juice delivered to the mills and distilleries is determined by the soluble solids, apparent sucrose, and the reducing sugars contents. These evaluations based on light deviation are adopted to have easy and fast result to the dynamics of samples during the harvest period (Oliveira et al., 2017). In this way, varieties that present better quality as raw material and, consequently, higher industrial yield for sugar and alcohol manufacture have great importance to achieve the technical and economic sustainability of the crop.

Based on the above, the objective of this study was to evaluate the industrial quality of four sugarcane varieties (RB92579, RB967515, SP813250 and VAT 90212) in three years that represent more than $50 \%$ of the cultivated area of Northeast of Brazil.

\section{Results and Discussion}

Fiber in the stalks and apparent sucrose (Pol) in the broth

There was no varietal effect for fiber content in the stalks during the three crop cycles (Table 2), with averages of $12.76,13.46$ and $14.91 \%$ for cane-plant, first and second ratoon, respectively. Fiber is a very important factor in the sugarcane agro-industry. The fiber-rich varieties have greater 
resistance to tipping, even when subjected to fire depletion, and are generally more resistant to pest penetration on the stem.

Simões et al. (2015), evaluated the physiological and technological variable responses of RB92579 under different irrigation management systems in three cycles and obtained fiber average values of $13.8 ; 14.9$; and $16.6 \%$ for cane-plant, first and second ratoon, respectively, which are higher values than those obtained in the present study. The high fiber content causes resistance to the extraction of the juice. The recommended value of fiber content for energy maintenance for the sugar-producing industries is from 10.5 to $12.5 \%$ (Oliveira et al., 2009). Fernandes (2000), reported that the average fiber content should be between 10 and $11 \%$. In the northeast region of Brazil the fiber content is higher mainly due to the higher evapotranspiration during cane harvest.

The apparent sucrose in the broth (Pol) did not present varietal effect for cane-plant and second regrowth (second ratoon). In the first regrowth (ratoon), RB867515 presented higher apparent sucrose content not statistically differing from SP813250 (Table 2). In cane-plant and second ratoon, averages were 14.84 and $16.54 \%$, respectively. In dry land areas, Oliveira et al. (2011a), reported the apparent sucrose content (Pol) of 18.2, 18,1 and 18,8 \% for RB92579, RB867515 and SP813250, respectively, under dry and irrigated water regime. In the State of Alagoas in forest zone, Oliveira et al. (2011b) obtained an average value of $16.6 \%$ in the first ratoon for RB867515, similar as the results of present study.

The apparent sucrose is the amount of sucrose present in $100 \mathrm{~g}$ of a solution. The higher the content more mature is the sugar cane. When sugarcane is immature it has higher amounts of reducing sugars and color precursor compounds that negatively affect apparent sucrose. In the sugar-alcohol sector the sucrose content is referred as Pol (Fernandes, 2000; Santos et al., 2011). Pol is one of the most important quality factors for the sugar cane industry, in which values above $14 \%$ is indication of good quality raw material.

\section{Purity and soluble solids (Brix) content in the broth}

For broth purity there was no varietal effect on the cane-plant cycle. However, there was variation influence for first and second ratoon (Table3). The variety that presented lower purity in the first regrowth was RB867515. The other varieties did not differ among one another. In the second regrowth, RB92579 presented lower purity. The average results of first ratoon and second ratoon crop were above those reported by Oliveira et al. (2011b) and Assis et al. (2004), respectively.

The purity represents the amount of sucrose contained in the soluble solids. It is an important indicator of the maturity of sugarcane. More maturity causes greater the accumulation of sucrose and consequently greater purity (Fernandes, 2000; Lavanholi et al., 2008). The aging of sugarcane causes deterioration of sucrose and decline in purity. High purity index is a foreshadowing of an ease manufacturing process, better quality of sugar and good industrial yields.

The soluble solid content was influenced by the varieties in the first and second regrowth cycle. At the first regrowth, the highest value of Brix was found for variety RB867515. The other varieties did not differ; however, in the second regrowth, VAT90212 presented worst performance (Table 3). Santos et al. (2011), evaluated the quality of the broth in RB867515 in the cane-plant cycle under filter cake fertilization and obtained values $15 \%$ higher than those found in the present study. In a study conducted in Rio Grande do Norte, Assis et al. (2004) found soluble solids content higher than the present study, possibly influenced by the higher air evaporative demand in the Rio Grande do Norte, Brazil, which results in more concentrated broth. In a study conducted in Paraíba, Brazil on the industrial quality of SP791011, the average value for the second regrowth was lower than that found by Carvalho et al. (2008) under different water irrigation availability.

The soluble content, called as Brix in the sugarcane sector, represents the most used variable in the sugar and alcohol industry and expresses the percentage of soluble solids contained in an impure sugary solution. The Brix is determined by refractometry or by density (Fernandes, 2000; Lavanholi et al., 2008) and has direct relationship with the sugar content in the broth. Generally, its concentration in the broth ranges from $18-25 \%$.

\section{Total recoverable sugars (TRS) and phosphorus inorganic (Pi) in the broth}

The total recoverable sugars (TRS) was influenced by varieties in the first and second ratoon cycles (Table 4). In first ratoon the highest values were found for SP813250 and RB867515. In second ratoon the highest was found for RB92579. The TRS average was 145,132 and $131 \mathrm{~kg} \mathrm{t}^{-1}$ for cane-plant, first and second regrowth, respectively. Oliveira et al. (2011a) did not observe significant difference between the TRS of RB92579, RB867515 and SP813250 at no irrigation condition with average values of 146,151 and 148 $\mathrm{kg} \mathrm{t}^{-1}$, respectively.

Inorganic phosphorus levels were influenced by the varieties in the three crop cycles. The VAT90212 was the cultivar with higher concentrations (Table 4). Phosphorus is a macronutrient that has great importance in the growth and development of plants, since it participates in the structural composition of macromolecules, such as nucleic acids, phospholipids and adenosine triphosphate. In sugarcane, $\mathrm{P}$ plays a key role in metabolism, particularly in the formation of proteins, cell division, photosynthesis, energy storage, splitting of sugars, respiration and energy supply from ATP and formation of sucrose (Calheiros et al., 2012; Caione et al., 2013).

For sugarcane broth, phosphorus is present in both mineral and organic forms (César et al., 1987; Oliveira et al., 2011b). Phosphate compounds are indispensable in the sugar manufacturing process; mainly in the process of clarifying the broth precipitating impurities. However, the lowphosphorus broth has difficulties in flocculation, which imply the production with lower sugar quality and lower commercial value (César et al., 1987; Martins, 2004; Oliveira et al., 2011b). Martins (2004) studies the inorganic phosphorus content in the broth with a range from 25 to 46 $\mathrm{mg} \mathrm{L}^{-1}$, representing approximately $5 \%$ of the total. César et al. (1987) described that in order to realize a good clarification of the sugarcane juice, the inorganic phosphorus content should be greater than $100 \mathrm{mg} \mathrm{dm}^{-3}$. 
Table 1. Results of chemical analyses of soil samples for layers $0-20 \mathrm{~cm}$ and $20-40 \mathrm{~cm}$.

\begin{tabular}{|c|c|c|c|c|c|c|c|c|c|}
\hline Layers & $\mathrm{pH}$ & $\mathrm{P}$ & $\mathrm{K}$ & $\mathrm{Ca}$ & $\mathrm{Mg}$ & $\mathrm{Al}$ & $\mathrm{H}+\mathrm{Al}$ & SB & $\mathrm{T}$ \\
\hline$-\mathrm{cm}-$ & \multicolumn{4}{|c|}{---mg dm ${ }^{-3}-$} & 10 & $---c$ & $n^{-3}---$ & ---- & \\
\hline $00-20$ & 5.9 & 103.0 & 40 & 1.8 & 0.8 & 0.0 & 3.80 & 2.70 & 6.5 \\
\hline $20-40$ & 5.0 & 21.6 & 20 & 0.6 & 0.3 & 0.6 & 4.62 & 0.95 & 5.57 \\
\hline $\begin{array}{l}\text { Prof } \\
-\mathrm{cm}-\end{array}$ & $\begin{array}{c}\mathrm{t} \\
\mathrm{cmolc} \mathrm{dm}^{-3}\end{array}$ & $\begin{array}{l}\mathrm{V} \\
--\end{array}$ & $\mathrm{m}$ & $\begin{array}{c}\text { MO } \\
\text { dag kg-1 }\end{array}$ & $\mathrm{Zn}$ & $\mathrm{Fe}$ & $\begin{array}{c}\mathrm{Mn} \\
\mathrm{C}\end{array}$ & $\mathrm{Cu}$ & B \\
\hline $00-20$ & 2.70 & 42 & 0 & 1.8 & 2.5 & 75.6 & $9.7^{\circ}$ & 1.1 & 0.4 \\
\hline $20-40$ & 1.55 & 17 & 39 & 0.8 & 0.4 & 53.4 & 0.3 & 0.2 & 0.3 \\
\hline
\end{tabular}

$\mathrm{pH}$ in $\mathrm{H}_{2} \mathrm{O}$ (Ratio 1:2.5). P K, Fe, Zn, Mn, and $\mathrm{Cu}$ : Mehlich extractor. Ca, Mg and $\mathrm{Al}$ : KCI extractor. H+Al: Calcium acetate extractor. B: Hot water extractor, S: Monocalcium phosphate in acetic acid extractor.

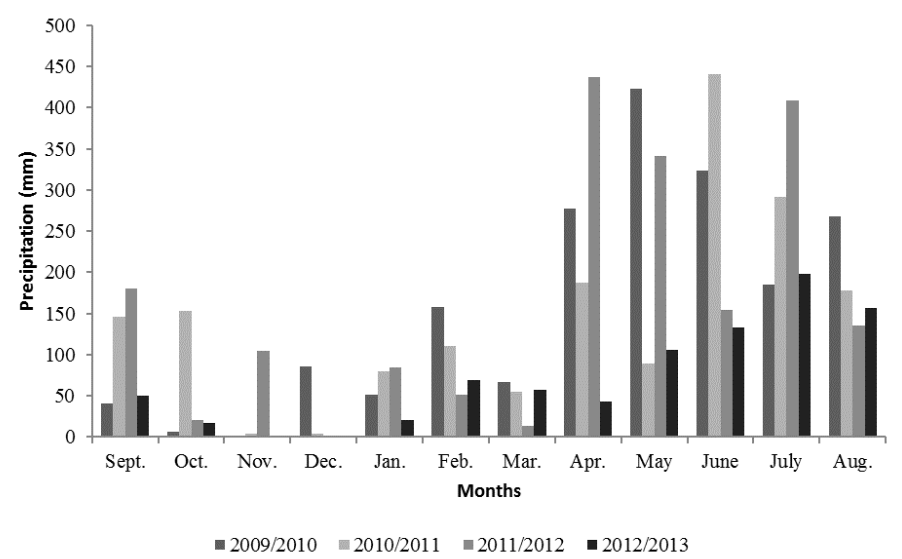

Fig 1. Monthly precipitation during the period studied (Silva et al. 2017 a).

Table 2. Fiber in the stalks and apparent sucrose (Pol) in the broth of four varieties of sugarcane in three cycles.

\begin{tabular}{llll}
\hline Varieties & $\begin{array}{l}\text { Fiber } \% \\
\text { Cane plant }\end{array}$ & First regrowth & Second ratoon \\
\hline VAT90212 & $12.67 \mathrm{a}$ & $13.40 \mathrm{a}$ & $14.49 \mathrm{a}$ \\
SP813250 & $12.58 \mathrm{a}$ & $13.16 \mathrm{a}$ & $15.64 \mathrm{a}$ \\
RB867515 & $12.85 \mathrm{a}$ & $13.54 \mathrm{a}$ & $14.88 \mathrm{a}$ \\
RB92579 & $12.96 \mathrm{a}$ & $13.73 \mathrm{a}$ & $14.62 \mathrm{a}$ \\
\hline Total average & 12.76 & 13.46 & 14.91 \\
C.V $(\%)$ & 4.15 & 4.63 & 6.42 \\
\hline & $14.68 \mathrm{a}$ & Pol $(\%)$ & $15.34 \mathrm{a}$ \\
VAT90212 & $15.13 \mathrm{a}$ & $15.63 \mathrm{a}$ & $16.64 \mathrm{a}$ \\
SP813250 & $14.65 \mathrm{a}$ & $16.65 \mathrm{~b}$ & $16.41 \mathrm{a}$ \\
RB867515 & $14.90 \mathrm{a}$ & $16.82 \mathrm{~b}$ & $17.78 \mathrm{~b}$ \\
RB92579 & 14.84 & $16.04 \mathrm{a}$ & 16.54 \\
\hline Total average & 5.95 & 16.28 & 5.58 \\
C.V $(\%)$ & 3.03 &
\end{tabular}

Table 3. Purity and soluble solids (Brix) content in the broth of four varieties of sugarcane. for cane plant. first and second ratoon.

\begin{tabular}{lccc}
\hline Varieties & Cane plant & $\begin{array}{c}\text { Purity } \% \\
\text { First ratoon }\end{array}$ & Second ratoon \\
\hline VAT90212 & $85.94 \mathrm{a}$ & $85.87 \mathrm{~b}$ & $85.73 \mathrm{a}$ \\
SP813250 & $85.65 \mathrm{a}$ & $84.96 \mathrm{~b}$ & $85.85 \mathrm{a}$ \\
RB867515 & $85.30 \mathrm{a}$ & $82.10 \mathrm{a}$ & $85.71 \mathrm{a}$ \\
RB92579 & $85.94 \mathrm{a}$ & $85.85 \mathrm{~b}$ & $87.75 \mathrm{~b}$ \\
\hline Total average & 85.74 & 84.62 & 86.26 \\
C.V $(\%)$ & 2.43 & 2.51 & 1.22 \\
\hline & & Brix $(\%)$ & $17.87 \mathrm{a}$ \\
VAT90212 & $17.08 \mathrm{a}$ & $18.21 \mathrm{a}$ & $19.38 \mathrm{~b}$ \\
SP813250 & $17.65 \mathrm{a}$ & $19.60 \mathrm{a}$ & $19.14 \mathrm{~b}$ \\
RB867515 & $17.15 \mathrm{a}$ & $20.53 \mathrm{~b}$ & $20.25 \mathrm{~b}$ \\
RB92579 & $17.31 \mathrm{a}$ & $18.75 \mathrm{a}$ & 19.16 \\
\hline Total Average & 17.3 & 19.27 & 4.58 \\
C.V $(\%)$ & 3.77 & 4.63 &
\end{tabular}


Table 4. Total recoverable sugars (TRS) and phosphorus inorganic (Pi) in the broth of four sugarcane varieties in three crop cycles. grown in the State of Alagoas.

\begin{tabular}{|c|c|c|c|}
\hline \multirow{2}{*}{ Varieties } & \multicolumn{3}{|c|}{ TRS kg t ${ }^{-1}$} \\
\hline & Cane plant & First ratoon & Second ratoon \\
\hline VAT90212 & $144.12 \mathrm{a}$ & $127.46 \mathrm{a}$ & $124.91 \mathrm{a}$ \\
\hline SP813250 & $148.39 \mathrm{a}$ & $136.19 \mathrm{~b}$ & $130.07 \mathrm{a}$ \\
\hline RB867515 & $143.95 \mathrm{a}$ & $137.14 \mathrm{~b}$ & $130.22 \mathrm{a}$ \\
\hline RB92579 & $146.20 \mathrm{a}$ & $129.93 \mathrm{a}$ & $140.63 \mathrm{~b}$ \\
\hline Total average & 145.67 & 132.68 & 131.46 \\
\hline \multirow[t]{2}{*}{ C.V (\%) } & 5.37 & 3.39 & 5.4 \\
\hline & & Pi kg t ${ }^{-1}$ & \\
\hline VAT90212 & $89 \mathrm{~b}$ & $73 \mathrm{~b}$ & $150 \mathrm{~b}$ \\
\hline SP813250 & $54 \mathrm{a}$ & $55 \mathrm{a}$ & $75 \mathrm{a}$ \\
\hline RB867515 & $35 \mathrm{a}$ & $44 \mathrm{a}$ & $74 \mathrm{a}$ \\
\hline RB92579 & $52 \mathrm{a}$ & $37 \mathrm{a}$ & $83 \mathrm{a}$ \\
\hline Total average & 57.5 & 52.25 & 95.5 \\
\hline C.V $(\%)$ & 29.38 & 21.27 & 15.42 \\
\hline
\end{tabular}

Means followed by the same letter do not differ statistically by Scott-Knott test at $5 \%$ probability

\section{Materials and methods}

\section{Description of the study environments}

The study was conducted in an open field located in the Jequiá Farm, in the county of Anadia, Alagoas (Latitude $09^{\circ}$ $41^{\prime} 04$ "S and Longitude $36^{\circ} 18^{\prime} 15$ "W). The experimental area was in Usina Triunfo, which is located in the county of Boca da Mata - AL. The climate of region is a rainy tropical with dry summers, according to Koppen 's classification with rainfall and temperatures annual average of $1,500 \mathrm{~mm}$ (Fig 1) and $29^{\circ}$, respectively.

The soil of the area was classified as a dystrophic Yellow Latosol (Embrapa, 2013) with medium texture and chemicals characterization were defined from soil samples collected in the layers $0.0-0.2 \mathrm{~m} ; 0.2-0.4 \mathrm{~m}$ (Table 1 ). Soil acidity was corrected using dolomitic limestone at a dose of $150 \mathrm{~kg} \mathrm{ha}^{-1}$, calculated to increase the saturation to $60 \%$. After the application of the limestone, the soil was plowed and grated and the grooves were opened for manual planting using sugarcane stalks with three buds per billets. The planting density varied 15 to 18 buds per meter of furrow.

\section{Experimental design, trial management and treatments}

The experimental design was a randomized block with five replicates, consisting of four sugarcane varieties: SP813250, RB867515, RB92579 and VAT90212 grown in plots of six grooves with 10.0 meters in length, spaced from 1.0 meters, totalizing $60 \mathrm{~m}^{2}$ of total area. The four central lines with six meters of length were considered for analysis, making up to $24 \mathrm{~m}^{2}$. These varieties were chosen based on their importance of being cultivated in up to $50 \%$ of the planted area of sugarcane in the Northeast of Brazil before implementation of the experiment (Silva et al., 2017a).

Soil fertilization was based on Usina Triunfo recommendation according to the results of soil analysis (Table 1), applying 60, 100 and $150 \mathrm{~kg} \mathrm{ha}^{-1}$ of $\mathrm{N}, \mathrm{P}_{2} \mathrm{O}_{5}$ and $\mathrm{K}_{2} \mathrm{O}$ into the bottom of the groove. The cane was harvested at 14 months and then measurement of factors were done in the main cane-plant, first and second regrowth ratoon) stages, each one lasting 12 months. In these cycles all treatments received $500 \mathrm{~kg} \mathrm{ha}^{-1}$ of the formula $20-05-25$.

\section{Variables analyzed and software for statistical analysis}

The cane-plant cycle lasted 14 months and the ratoons 12 months each. Harvest was carried out with cane maturation, and the agro-industrial quality of the four varieties was evaluated. Sampling was collected from the four central grooves of the plot. A sub-sample of 10 stalks was collected, which were chopped and pressed at $250 \mathrm{kgf} \mathrm{cm}^{-2}$ for sixty seconds (Fernandes, 2000). The obtained juice was analyzed for the contents of soluble solids, apparent sucrose, purity, inorganic phosphorus and total recoverable sugars (TRS) Cesar et al. (1987) and Fernandes (2000).

The data were analyzed using the Sisvar computer program (Ferreira, 2011). The variables were submitted to the analysis of variance by the F-test, and the significant data were subjected to Scott Knott's test at a 5\% probability.

\section{Conclusion}

The sugarcane agro-industrial quality was influenced among varieties. However, no variety presented highest values for all attributes of quality evaluated.

\section{Acknowledgments}

The authors are grateful to $\mathrm{CNPq}$ - Conselho Nacional de Desenvolvimento Científico e Tecnológico "Brazilian Scientific and Technological Development Council", FACEPE -Fundação de Amaparo à Ciência e Tecnologia do Estado de Pernambuco "Foundation for the Support of Science and Technology of the State of Pernambuco, and CAPES - Coordenação de Aperfeiçoamento de Pessoal de Nível Superior "Coordination to the Improvement of Education Personnel", for the financial support and scholarships.

\section{References}

Assis PCO, Lacerda LD, Azevedo HM, Dantas J, Farias CHA (2004) Resposta dos parâmetros tecnológicos da cana-deaçúcar a diferentes lâminas de irrigação e adubação. R Biol Cien Ter. 4(2): 1-12.

Caione G, Fernandes FM, Lange A (2013) Efeito residual de fontes de fósforo nos atributos químicos do solo, nutrição e produtividade de biomassa da cana-de-açúcar. R Bras Cien Agrar. 8(2): 189-196.

Calheiros AS, Oliveira MW, Ferreira VM, Barbosa GVS, Santiago AD \& Aristides EVS (2012) Produção de biomassa, a partir de açúcar e proteína em função de variedades de cana-de-açúcar e adubação fosfatada Semin Cien Agrar. 33(2): 809-818. 
Carvalho CM, Azevedo HM, Dantas Neto J, Melo EP, Silva CTS, Gomes Filho RR (2008) Resposta dos parâmetros tecnológicos da terceira folha de cana-de-açúcar submetida a diferentes níveis de irrigação. R Bras Cien Agrar. 3(4): 337-342.

Cesar MAA, Delgado AA, Camargo AP, Bissoli BMA, Silva FC (1987) Capacidade de fosfatos naturais e artificiais em elevar o teor de fósforo no caldo de cana-de-açúcar (canaplanta), visando o processo industrial. Stab. 5(2): 32-38.

Conab (2016) Companhia Nacional de Abastecimento. Acompanhamento da safra brasileira: cana-de-açúcar. Primeiro Levantamento, 66p.

Embrapa - Empresa Brasileira de Pesquisa Agropecuária (2013) Sistema brasileiro de classificação de solos. $3^{\mathrm{a}}$ ed. Brasília, DF; 2013, 353p.

Fernandes AC (2000) Cálculos na agroindústria da cana-deaçúcar. STAB - Sociedade das Técnicos Açúcareiro e Alcooleiros do Brasil. 193p.

Ferreira DF (2011) Sisvar: a computer statistical analysis system. Cienc Agrotec. 35 (6): 1039-1042.

Martins NGS (2004) Os fosfatos na cana-de-açúcar. Dissertation, Universidade de São Paulo, Piracicaba, 2004.

Mohammed H, Solomon WK, Bultosa G (2016) Optimization of phosphate and anionic polyacrylamide flocculant (apf) level for sugar cane juice clarification using central composite design. J Food Process Preserv. 40 (1): 67-75.

Oliveira DC, Oliveira MW, Pereira MG, Gomes TCA, Silva VSG, Oliveira TBA (2017) Stalk productivity and quality of three sugarcane varieties at the beginning, in the middle, and at the end of the harvest. Afr J Agr Res. 12 (4): 260269.

Oliveira ECA, Freire FJ, Oliveira AC, Neto DES, Rocha AT, Carvalho LA (2011a) Productivity, water use efficiency, and technological quality of sugarcane subjected to differents water regimes. Pesq agropec bras. 46 (6): 617625.

Oliveira EL, Andrade LAB, Faria MA, Evangelista AWP, Morais AR (2009) Use of pot still vinasse and nitrogen in irrigated and unirrigated sugar cane. Pesq agropec bras. 44(11):1398-1403.
Oliveira MW, Silva VSG, Reis LS, Oliveira DC, Silva JCT (2015) Produção e qualidade de três variedades de cana-deaçúcar cultivadas no nordeste de Minas Gerais. R Ciência Agrícola. 12 (1): 17-20.

Oliveira FM, Aguilar PB, Teixeira MFF, Aspiazú I, Monção FP, Antunes APS (2014). Agrotecnólogical characteristics of cane sugar at different times of suppression of irrigation and fertilizer levels. Semin Cien Agrar. 35(3):1587-1606.

Oliveira MW, Magrini JL, Lyra, FEV, Valduga GR, Pereira MG, Tenorio CJM, Aristides EVS (2011b) Produção da RB867515 influenciada pela aplicação de substâncias húmicas, aminoácidos e extrato de algas marinhas. Stab. 30(1): 30-33.

Lavanholi MGDP (2008) Qualidade da cana-de-açúcar como matéria prima para a produção de açúcar e álcool. In: Dinardo -Miranda LL, MGA (Org.) Cana-de-acucar. 1: 697-722.

Rhein A FL, Pincelli RP, Arantes MT, Dellabiglia WJ, Kölln OT, Silva MA (2016) Technological quality and yield of sugarcane grown under nitrogen doses via subsurface drip fertigation. Rev Bras Eng Agric Ambient. 20(3):209-214.

Santos DH, Silva MA, Tiritan CS, Foloni JSS, Echer FR (2011) Technological quality of sugarcane under fertilization with filter cake enriched with soluble phosphate. Rev Bras Eng Agric Ambient. 15 (5): 443-449.

Silva VSG, Oliveira MW, Oliveira DC, Oliveira TBA, Pereira MG, Nogueira CHC (2017 a) Nutritional diagnosis of sugarcane varieties in a Yellow Oxisol during three agricultural seasons. Afr J Agr Res. 12 (1): 50- 60.

Silva VSG, Oliveira MW, Oliveira TBA, Mantovanelli BC, Da Silva ACI, Soares ANR, Clemente PRA (2017b) Leaf area of sugarcane varieties and their correlation with biomass productivity in three cycles. Afr J Agr Res. 12 (7): 459-466.

Simões WL, Calgaro M, Coelho DS, Souza MA, Lima JA (2015) Physiological and technological responses of sugarcane to different irrigation systems. Rev Cien Agron. 46 (1):11-20. 